\title{
BIPLOT ANALYSIS FOR SPOT BLOTCH AND YIELD TRAIT USING WAMI PANEL OF SPRING WHEAT
}

\section{Ram Narayan Ahirwar ${ }^{1}$, Vinod Kumar Mishra ${ }^{1 *}$, Dwijesh Chandra Mishra ${ }^{2}$, Neeraj Budhlakoti ${ }^{2}$, Shweta Singh ${ }^{3}$, Ramesh Chand ${ }^{4}$}

1Department of Genetics and Plant Breeding, Institute of Agricultural Sciences, Banaras Hindu University, Varanasi-221 005, India

2ICAR- Indian Agricultural Statistical Research Institute, New Delhi-110012, India

${ }^{3}$ Department of Botany, Institute of Science, Banaras Hindu University, Varanasi-221 005, India

${ }^{4}$ Department of Mycology and Plant Pathology, Institute of Agricultural Sciences, Banaras Hindu University, Varanasi-221 005, India

Received - February 17, 2020; Revision - April 03, 2020; Accepted - April 19, 2020

Available Online - April 25, 2020

DOI: http://dx.doi.org/10.18006/2020.8(2).115.124

KEYWORDS
Wheat
Spot blotch
AUDPC
Eastern Gangetic Plains and
GGE biplot

GGE biplot

\begin{abstract}
Wheat (Triticum aestivum L.) is a staple food worldwide. Spot Blotch (SB) has been a major disease for cultivation of wheat in Eastern Gangatic Plain (EGP). The goal of this study was to evaluate genetically diverse, advanced elite lines of wheat association mapping initiative (WAMI) population to identify useful genetic diversity and other related traits for spot blotch resistance present in WAMI panel for wheat improvement. A panel of 289 elite lines of WAMI population were assessed for spot blotch resistance, days to heading and plot yield for three consecutive years (2012-13, 2013-14 \& 2014-15). The significant differences among genotype, year and genotype $\times$ year for area under disease progress curve (AUDPC), days to heading and plot yield were exhibited. The negative correlation between days to heading and spot blotch AUDPC was observed whereas, AUDPC and days to heading was significantly and negatively correlated with plot yield. Based on GGE biplot, the first two principal components explained $100 \%, 100 \%$ and $84.5 \%$ of the total variation for AUDPC, days to heading and plot yield respectively. Germplasms 9122, 9049 and 9239 were showed most resistant under study. The highest mean value for plot yield was observed for the panel 9061, 9070, 9203, 9216, 9118 and 9227 which were found relatively more stable for grain yield. These genotypes could be used in wheat improvement programmes for developing superior genotypes for yield and spot blotch resistance contributing to food security in south Asia.
\end{abstract}

* Corresponding author

E-mail: vkmbhu@gmail.com (Vinod Kumar Mishra)

Peer review under responsibility of Journal of Experimental Biology and Agricultural Sciences.

Production and Hosting by Horizon Publisher India [HPI] (http://www.horizonpublisherindia.in/).

All rights reserved.
All the articles published by Journal of Experimental Biology and Agricultural Sciences are licensed under a Creative Commons Attribution-NonCommercial 4.0 International License Based on a work at www.jebas.org.

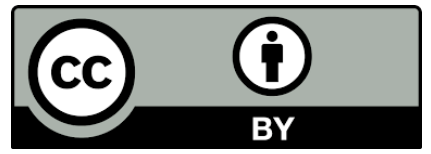




\section{Introduction}

Wheat is most important and widely cultivated cereal crop throughout the world and remains a vital source for human food (FAOSTAT, 2016), contributes substantially to human daily calories and food security (Braun et al., 2010). Gradually and consistently wheat demand has been always increasing in the developing world. The world population expected to increase over 9 billion by 2050, the demand of wheat consumption will be increase by $60 \%$ compared with 2010 . To fulfill this demand, global annual yield of wheat must increase from the current $1 \%$ per year (2001-2010) to 1.6\% per year (2011-2050) (Giraldo et al., 2019). Biotic and abiotic stresses are major constraints leading to more impacts in productivity of wheat. Among biotic stresses, spot blotch has emerged as major challenge in the eastern parts of India; some reports indicated that this disease also spread into the cooler traditional rice-wheat production areas (Chand et al., 2003).

Spot blotch is a fungal disease caused by pathogen Bipolaris sorokiniana and it is considered as most important and destructive disease in the region having warm and humid climate of the world, restraining wheat production in the areas such as eastern India, South East and Latin America, the tarai of Nepal, China and Africa (Raemakers 1988; Saari 1998). Due to wide spread losses, this disease is considered as the most significant disease of wheat in north-eastern plain zone (NEPZ) of India encompassing eastern Utter Pradesh, Bihar, West Bengal and Orissa (Saari 1998; Joshi et al.,2007b). Due to losses caused by this disease, wheat breeders rank this disease as number one disease in NEPZ of India (Saari, 1998; Joshi \& Chand, 2002). Disease severity is affected by crop management, soil fertility, planting density, the development stage of the plant and the weather conditions experienced by the host during later part of life cycle (Joshi et al., 2007b). Particularly in grain filling stage, this disease becomes more severe (Joshi \& Chand, 2002) and in Indian subcontinent, the crop losses have been reported to be in range of $15-25 \%$ (Dubin \& Van Ginkel, 1991), but level of losses can be much higher in individual fields. Reports from several countries indicated that average yield loss due to spot blotch is estimated to be $15-20 \%$ but can reach $40-70 \%$ in susceptible genotypes (Fernandez et al., 2014).

Many effort has been done to control spot blotch disease but only integrated approach is considered most effective component (Joshi \& Chand, 2002; Duveiller, 2003). However, in some instances, only resistant varieties prove to be controlling this disease. Wheat variety that possess high yield, early maturity along with resistance to spot blotch disease could be best in NEPZ. However, a negative correlation between spot blotch susceptibility and early maturity was observed by many researchers (Dubin et al., 1998; Shrestha et al., 1998). The primary focus of disease control relies on genetic resistance that involves race non-specific mechanism. Use of resistant cultivars is the best way to control this disease (Bai \&
Shaner, 1994; Chaurasia et al., 1999). Although in recent years, significant effort has been made by wheat breeding programs targeting Indian gangetic plains, most cultivars grown in the subcontinent still harbor relatively low level of resistance to foliar blight (Joshi et al.,2004b).

Keeping in view of increasing threat of spot blotch disease and more heat stress to the wheat crop, there is necessity to identify and develop genetically improved germplasm incorporating earliness, tolerance and resistance to spot blotch for EGP of south Asia. In this study, an attempt has been made to identify the germplasms belong to south Asia which are tolerant to spot blotch disease by analyzing the genotype $\mathrm{x}$ environment interaction in WAMI panel of wheat.

\section{Materials and methods}

The experimental materials comprised of 289 genetically diverse, high-yielding, advanced elite lines of wheat association mapping initiative (WAMI) population of wheat obtained from Matthew Reynolds, CIMMYT Mexico.

\subsection{Experimental design and trait evaluation}

The WAMI population was evaluated at agricultural research farm of Banaras Hindu University, Varanasi, India ( $25^{\circ} 18^{\prime} \mathrm{N}$ lat., $83^{\circ} 03^{\prime}$ E long. and $75 \mathrm{~m}$ amsl.) for three consecutive years i.e., 2012-13, 2013-14 and 2014-15. The mean temperatures (November-April) during 2012-13, 2013-14 and 2014-15 was $26.12^{\circ} \mathrm{C}, 25.41^{\circ} \mathrm{C}$ and $23.21^{\circ} \mathrm{C}$ respectively and mean annual rainfall was $737.7,932.7$ and $1009.4 \mathrm{~mm}$ respectively. The experiment field was followed by rice-wheat cropping system and conducted under irrigated conditions. The sowing of crop was done from $1^{\text {th }}$ to $10^{\text {th }}$ December during three consecutive rabi season. The experiment was laid out in alpha lattice design with two replications and each genotype was sown in two rows of two meters long plot under irrigated conditions maintaining row-to-row distance $20 \mathrm{~cm}$ and plant toplant $5 \mathrm{~cm}$. The genotypes were allocated randomly to each replication using Fisher and Yates Random Table (Panse \& Sukhatme, 1985). Recommended fertilizer dose (120 kg N: $60 \mathrm{~kg}$ $\mathrm{P}_{2} \mathrm{O}_{5}: 40 \mathrm{~kg} \mathrm{~K} \mathrm{~K}_{2} \mathrm{O}$ in per ha) were applied in field. Full amount of $\mathrm{K}_{2} \mathrm{O}$ and $\mathrm{P}_{2} \mathrm{O}_{5}$ were supplied as single dose at sowing, while Nitrogen was given in three split doses: $60 \mathrm{~kg}$ per ha at sowing, 30 $\mathrm{kg}$ at the time of the first irrigation (21 days after sowing-DAS) and remaining $30 \mathrm{~kg}$ at the time of the second irrigation (45 DAS). Data was recorded for spot blotch severity, days to heading, plot yield (grain yield of 50 spikes) and 1000 grain weight.

\subsection{Inoculation of pathogen and disease assessment}

For creating artificial epiphytotic conditions, the most aggressive isolate of B. sorokiniana (NABM MAT1; NCBIJN128877, BHU, Varanasi, India) obtained from the department of mycology and 
plant pathology, Banaras Hindu University, Varanasi (Joshi \& Chand, 2002) was used. The isolate was purified, multiplied on potato dextrose agar (PDA) medium and the mass culture was produced on sorghum grains. A spore suspension adjusted to $10^{4}$ spores per $\mathrm{ml}$ of water using haemocytometer and applied during the evening hours as per the method of Chaurasia et al. (1999). The field was irrigated immediately after inoculation to ensure spore germination and disease development. Frequent irrigation were given to provoke environmental conditions facilitate to spot blotch.

For area under disease progress curve (AUDPC), disease severity (\%) was recorded on each germplasm line of artificially inoculated plots at three different growth stages (GS) viz., GS 63 (beginning of anthesis to half complete), GS 69 (anthesis complete) and GS 77 (late milking) by using Saari \& Prescott (1975) double digit (00 to 99) method. The first digit (D1) indicates vertical disease progress on the plant and the second digit (D2) indicates severity measured in diseased leaf area. Disease severity was then used to estimate the AUDPC by following formula given by Shaner \& Finney (1977).

$$
A U D P C=\sum_{i=0}^{n-1}\left[\left\{\left(Y_{i}+Y_{i+1}\right) / 2\right\} \times\left(t_{i+1}-t_{i}\right)\right]
$$

Where, $Y_{i}=$ disease severity at time $t_{i},\left(t_{i+1}-t_{i}\right)=$ Time (days) between two disease scores, $n=$ number of dates at which spot blotch was recorded.

\subsection{Statistical analysis}

Analysis of variance (ANOVA) for the traits was performed using proc GLM procedure of SAS version 9.2 statistical software to determine the contribution of genotypes, year and their interactions. The association study among traits was estimated by using the Proc CORR procedure in SAS in terms of Pearson's correlation coefficients.

GGE biplot GUI package of R software was used to estimate the genotype $\times$ year interaction, to test the most discriminating years, which-won-where/what pattern, identify most stable lines over years using first two principal components (PC1 and PC2) derived from principal component (PC) analysis of environment-centered data (Yan, 2001).

\section{Results}

The analysis of variance of 289 WAMI panels tested over 3 years at Varanasi, India showed significant differences among genotype, year and genotype $\times$ year for AUDPC and, days to heading and plot yield (Table 1). A negative and non-significant phenotypic correlation was observed between AUDPC and days to heading whereas, AUDPC was significantly and negatively correlated with plot yield and while days to heading revealed significant negative associated with plot yield (Table 2).

Out of three years, highest mean of relative humidity was recorded in the year 2014-15 at BHU, Varanasi. The highest mean value for AUDPC was observed for the genotypes during the year 2014-15 as shown in GGE biplot (Figure 2A \& B). It is evident that the high humidity during booting to milking stage of wheat provokes spot botch (Figure 1B). As the minimum temperature increases during night resulted more chances of disease occurrence (Table 3). It was observed that humidity is more important than the temperature for spot blotch development whereas, resistant genotype under study shows independent of years. Hence, the selection of these lines will be beneficial for the farmers.

Table 1 Pooled variance components due to genotypes, year and $\mathrm{G} \times \mathrm{Y}$ interaction for 3 quantitative traits in 289 WAMI panels of wheat tested in three years at BHU, Varanasi, India

\begin{tabular}{|ccccc|}
\hline Source & d.f. & AUDPC & Mean sum of squares of 3 years \\
& & $102858.93^{*}$ & Days to heading & Plot yield \\
\hline Genotype & 288 & $549899.51^{*}$ & $11.25^{*}$ & $444.45^{*}$ \\
\hline Year & 2 & 10776.34 & $4072.36^{*}$ & $1709.12^{*}$ \\
\hline Replication & 1 & $18904.76^{*}$ & $122.56^{*}$ & $231.31^{*}$ \\
\hline Genotype $\times$ Year & 576 & 3319.37 & $3.50^{*}$ & $118.03^{*}$ \\
\hline Error & 866 & & 1.18 & 34.39 \\
\hline
\end{tabular}

*Significant at the $\mathrm{p}$-value $(\mathrm{P}<0.01)$ probability level.

Table 2 Correlation among AUDPC, days to heading (DH)and plot yield (PY).

\begin{tabular}{|ccc|}
\hline & AUDPC & DH \\
\hline DH & -0.01 & \\
\hline PY & $-0.21 *$ & $-0.07 *$ \\
\hline * Significant at $P<0.05$. & & \\
\hline
\end{tabular}

Journal of Experimental Biology and Agricultural Sciences http://www.jebas.org 

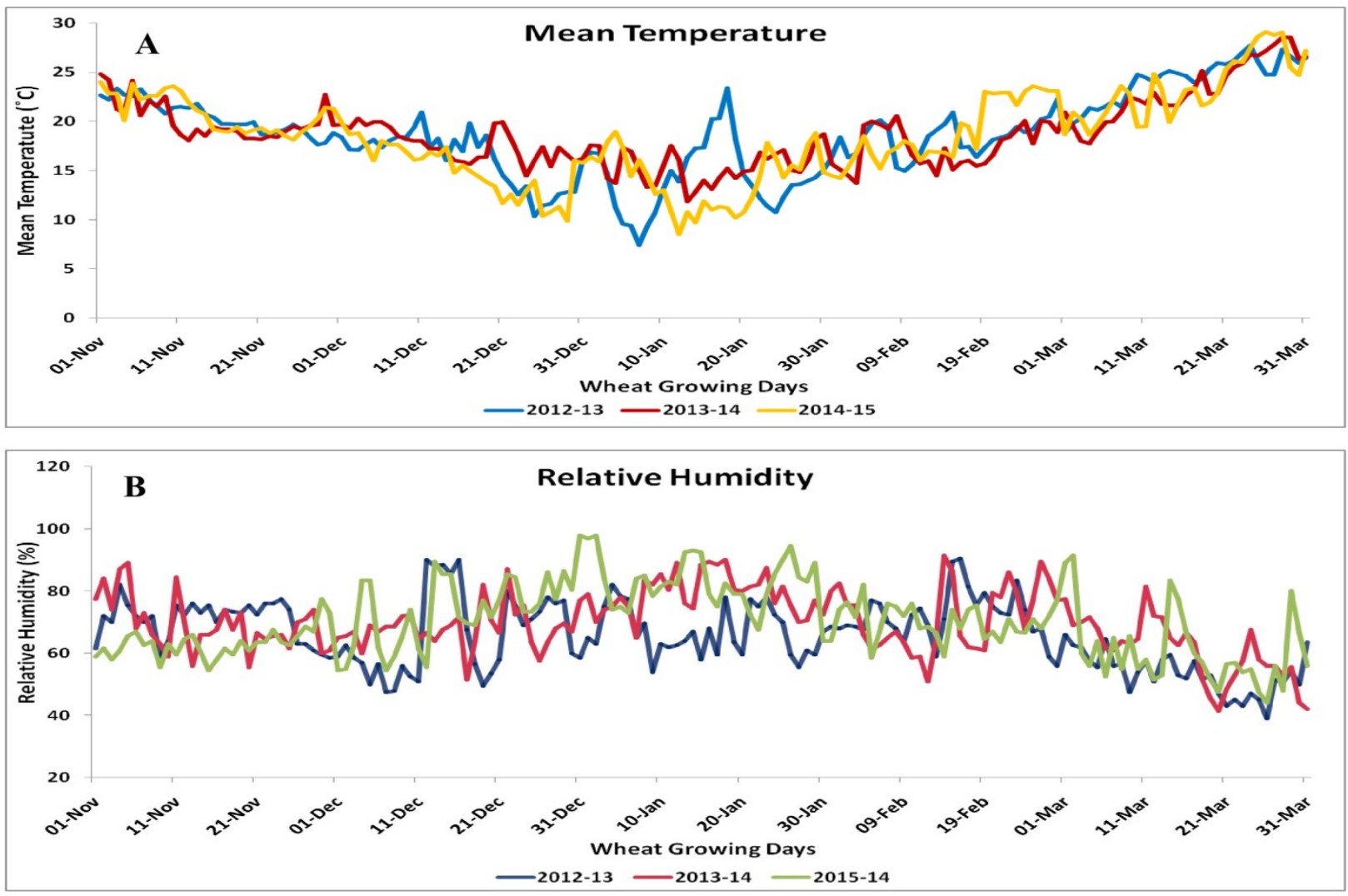

Figure 1 (A) Mean temperature (B) Relative humidity (\%) during wheat growing period over three year at BHU, Varanasi.

Table 3 Monthly mean minimum temperature $\left(\operatorname{Tmin}\right.$. in $\left.{ }^{\circ} \mathrm{C}\right)$ and Relative humidity $(\mathrm{RH} \%)$ at the test center in three years

\begin{tabular}{|ccccccccccc|}
\hline \multirow{2}{*}{ Month } & \multicolumn{3}{c}{ Year 2012-13 } & \multicolumn{3}{c}{ at Banaras Hindu University, Varanasi } & \multicolumn{3}{c}{ Year 2013-14 } & \multicolumn{3}{c|}{ Year 2014-15 } \\
\cline { 2 - 11 } & T max. & T min. & RH & T max. & T min. & RH & T max. & T min. & RH \\
\hline Nov. & 26.74 & 11.53 & 70.16 & 26.61 & 11.71 & 66.78 & 27.16 & 11.46 & 63.63 \\
\hline Dec. & 21.99 & 10.35 & 66.16 & 23.81 & 11.65 & 67.66 & 21.14 & 9.4 & 73.02 \\
\hline Jan. & 20.8 & 7.75 & 66.73 & 19.54 & 11.34 & 79.19 & 16.58 & 10.31 & 83.06 \\
\hline Feb. & 24.43 & 12.3 & 72.52 & 22.33 & 12.5 & 71.46 & 17.91 & 13.51 & 69.88 \\
\hline Mar. & 31.28 & 16.67 & 53.11 & 29.68 & 16.5 & 61.82 & 29.57 & 16.95 & 61.32 \\
\hline Apr. & 37.79 & 20.36 & 38.93 & 36.77 & 20 & 34.47 & 34.62 & 20.39 & 52.27 \\
\hline $\begin{array}{c}\text { Overall } \\
\text { mean }\end{array}$ & 26.12 & 12.58 & 62.23 & 25.41 & 13.61 & 66.09 & 23.21 & 13.21 & 69.35 \\
\hline
\end{tabular}

\subsection{GGE biplot results}

The first principal component (PC1) accounted for $75.13 \%$ of total variation and the second principal component (PC2) accounted for $24.87 \%$. Cumulatively; these two principal components explained approximately $100 \%$ variation for AUDPC (Figure 2A, B and C). The polygon is formed by connecting the markers of the WAMI panel that are further away from the biplot origin, such that all other panels come within the polygon (Figure 2A). The polygon also contains number of lines perpendicular to each side of the polygon. These perpendicular lines divide the biplot into sectors. The vertex panel in each sector represents the highest AUDPC panel in the year that falls within that particular sector (Yan $\&$ Tinker, 2005; Yan et al., 2010). The figure 1A has nine sectors

Journal of Experimental Biology and Agricultural Sciences http://www.jebas.org 

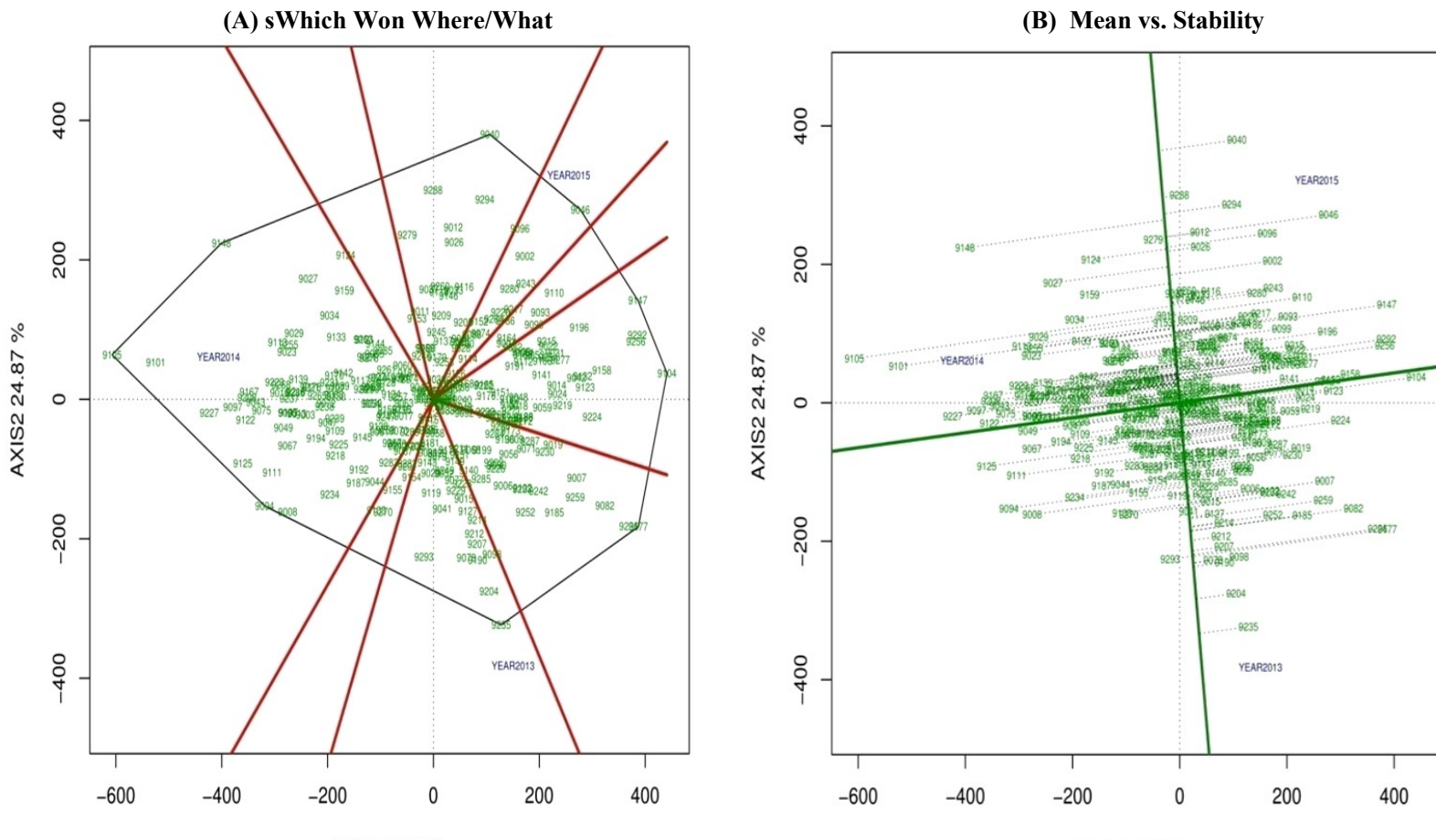

AXIS1 $75.13 \%$

(C) Ranking Genotypes

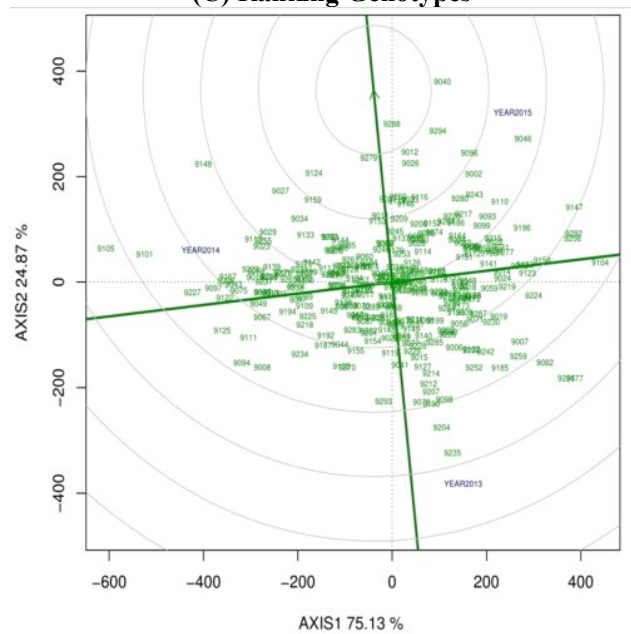

Figure 2 (A) 'Which-won-where/what view of genotype $\times$ year biplot (B) The mean vs. stability view of genotype $\mathrm{x}$ year interaction effect (C) Ranking of genotype for AUDPC over the years.

with vertex panels 9296, 9177 9235, 9094, 9105, 9148, 9040, 9046, 9147 and 9104. The vertex panels 9296,9177 and 9235 fell in the sector of year 2013 indicating that these panels were gave highest AUDPC for that particular year. Panels 9105, 9094 and 9148 were the highest AUDPC panels in the year 2014 while panels 9040, 9046, 9147 and 9104 were the highest AUDPC panels in the year 2015. Panels that fell within the polygon were less responsive than the vertex panels. The three years fell into three different sectors. This pattern implies that the target years may consist of three different environments and that different panel should be selected and utilized for each. Using the mean vs. stability GGE biplot of AUDPC for the 289 WAMI line as shown in Figure 2B, the vertical line separates lines with below-average means from those with above-average means. The mean AUDPC is estimated by the projections of their markers on the average-tester axis. The stability of the panels is determined by their projection onto the middle horizontal line. The greater the absolute length of the projection of a panel, that panel indicates less stable. In present study, the highest mean value for AUDPC was observed for 
the panels 9104 followed by $9158,9012,9132,9014$ and 9176 that were consistently more susceptible by being longest vector on the right side of the origin of the biplot on the performance line. On the other hand, panels 9122,9049 and 9239 were consistently most resistant by being longest vector on the left side of the origin of the biplot on the performance line. The performance of lines 9040, 9288, 9235 and 9204 were highly variable over the years, but the resistant panels $(9122$, 9239 and 9049) were more stable over the years.

The first principal component (PC1) accounted for $57.44 \%$ of total variation and the second principal component (PC2) also accounted for $42.56 \%$ for days to heading (Figure $3 \mathrm{~A}$ ). The vertex genotypes were 9175, 9228, 9131, 9130, 9001, 9147, 9112, 9180 and 9193. These genotypes had the longest distance from the origin of the biplot and showed the late or early headed genotypes over the years under study. Genotypes 9180, 9193, 9112, 9137 and 9227 had the late heading by being longest distance from the origin of the biplot on the right side of the performance line, while genotypes $9131,9195,9130$ and 9045 had the earliest days to heading. The performance of lines 9198, 9133, 9216 and 9235 were unstable for days to heading by being greater the absolute length of the projection of a panel in either side of horizontal line (Figure 3B). The ideal genotype showed both highest mean and stable thus using ideal genotype as the center, concentric circles were drawn to help visualize the distance between each genotype and the ideal genotype (Figure 3C). On the basis of relative position of ideal
(A) Which Won Where/What

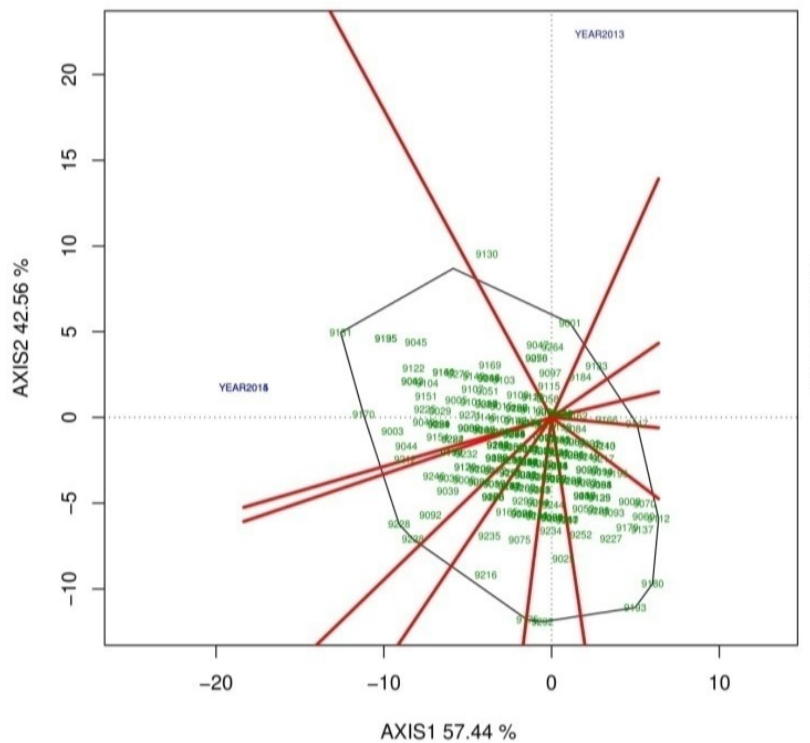

(B) Mean vs. Stability

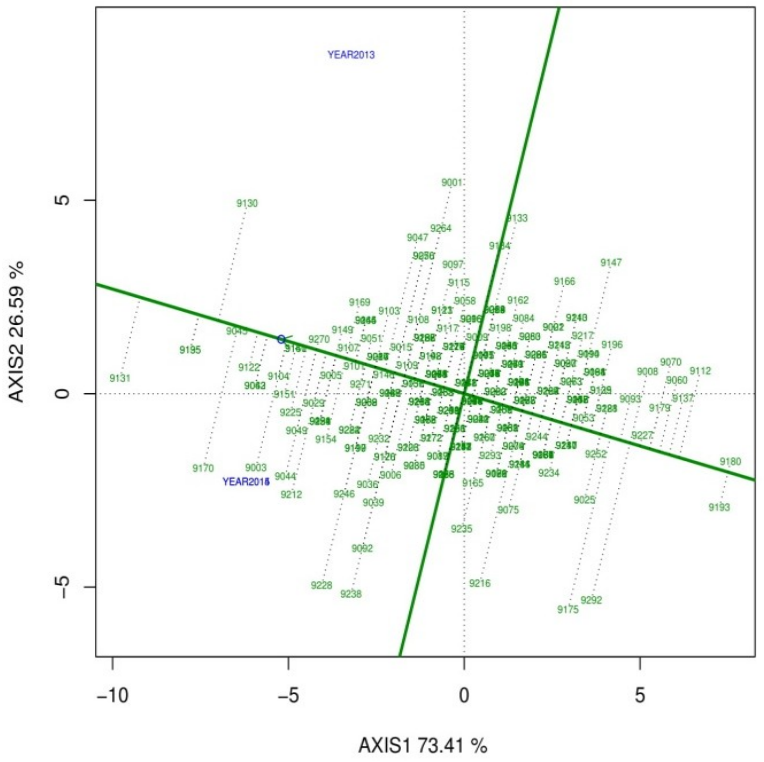

(C) Ranking Genotypes

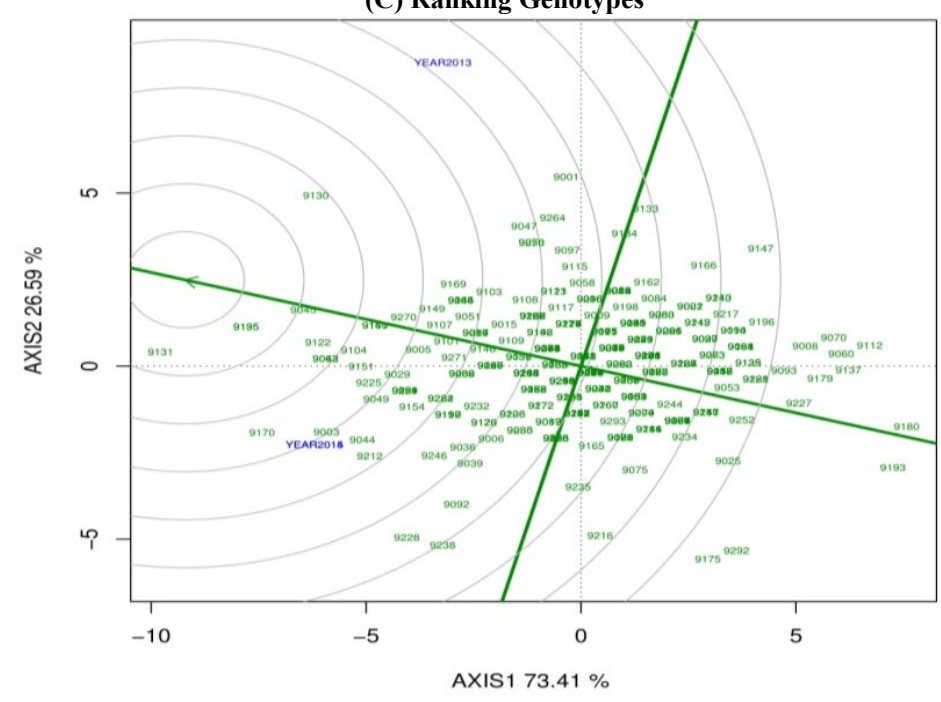

Figure 3 (A) "Which won where/what" of genotype $\times$ year biplot

(B) The mean vs. stability view of genotype $\times$ year interaction effect (C) Ranking of genotype based on days to heading the year.

Journal of Experimental Biology and Agricultural Sciences http://www.jebas.org 
genotype, the ranking of genotype are done. Therefore, genotypes placed closer to the ideal genotype are more desirable than others. Thus genotype 9195, 9131 and 9045 were regarded as ideal genotype and more favorable than all the other genotypes. The other genotypes were distantly placed from ideal genotypes declared unfavorable one.

The first \& second principal component explained $64.3 \%$ and $20.2 \%$ variation respectively. In total, both principal components explained $84.5 \%$ of the total variation for the plot yield (Figure 4A, B and C).
In this polygon, perpendicular lines are drawn from the biplot origin gave 10 sectors with vertex genotypes 9036, 9170, 9131, 9104, 9070, 9061, 9203 and 9255 of the polygon (Figure 4A). The property of biplot polygon view is that each vertex genotype has higher yield than the other genotypes that fall in the related sector (Yan, 2002). GGE biplot were used for graphically visualization of performance and stability of genotypes (Figure 4B). The highest mean value for grain yield was observed for genotypes 9061, 9070, 9203, 9216, 9118 and 9227. Genotypes with highest mean value could be
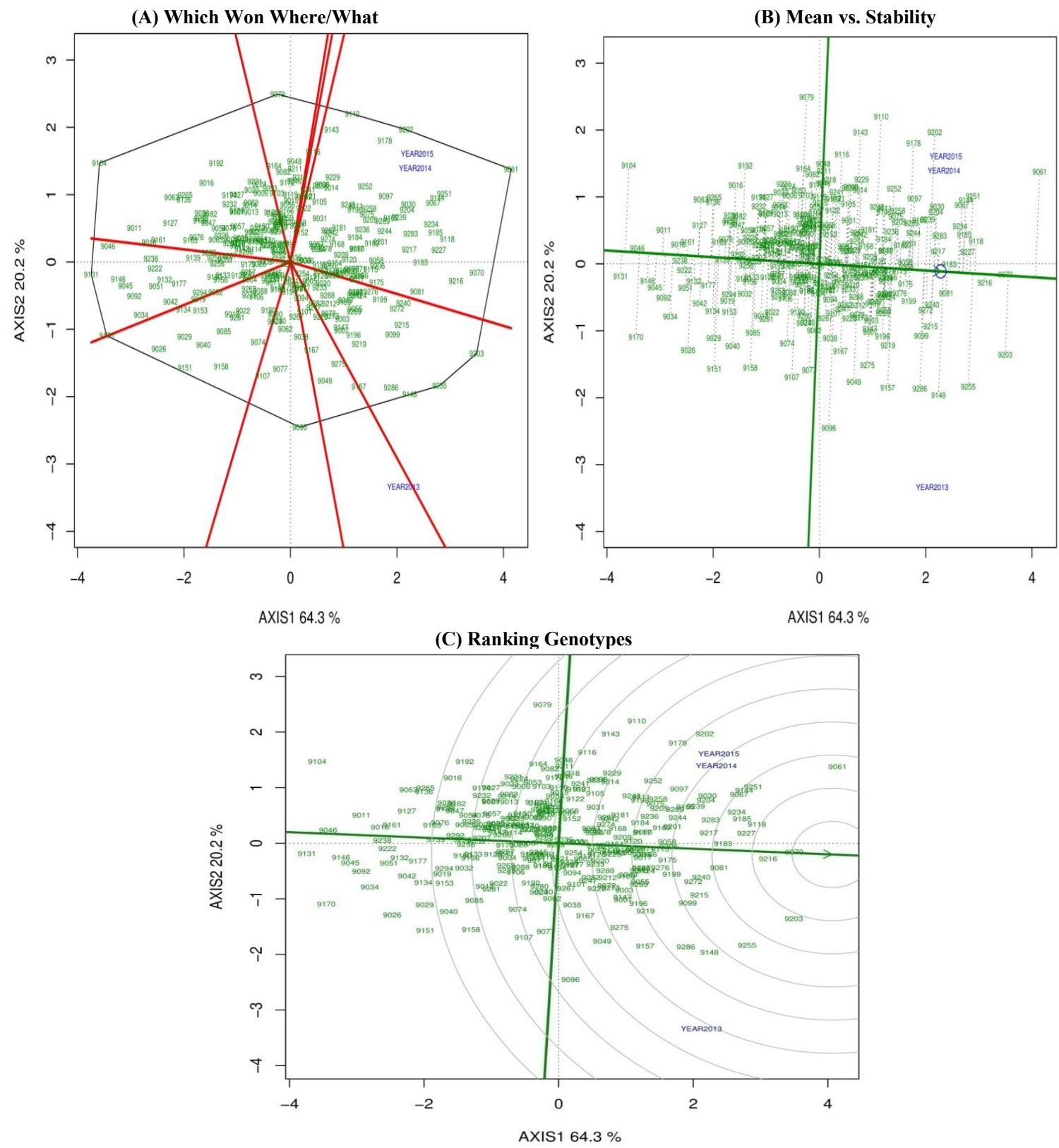

Figure 4 (A) "Which won where/what" view of genotype $\times$ year biplot (B) The mean vs. stability view of genotype $\mathrm{x}$ year interaction effect (C) Ranking of genotype based on plot yield over the year.

Journal of Experimental Biology and Agricultural Sciences http://www.jebas.org 
selected, whereas the rest were discarded. The ideal genotypes identified were 9070 followed 9216, 9227, 9118, 9183 and 9183 for plot yield (Figure 4C).

\section{Discussion and Conclusion}

Spot blotch caused by a fungus $B$. sorokiniana is an important disease in wheat production. It has become more devastating disease in the warmer areas of the world particularly the Indian subcontinent characterized by prevalent warm and humid conditions (Aggarwal et al., 2010). Further, the wide spread use of conservation tillage practices may also be favorable for spot blotch incidence in the south east Asia (Duveiller \& Sharma, 2009). It has been reported that this pathogen spread into the cooler traditional rice-wheat production areas (Chand et al., 2003). The extensively adopted rice-wheat cropping system facilitates suitable environment for the survival and multiplication of foliar blight pathogens in south Asia. It is generally believed that the level of resistance in high-yielding wheat genotypes is still unsatisfactory and needs to be improved significantly in warmer humid regions of south Asia (Sharma \& Duveiller, 2006; Joshi et al., 2007a). Consequently, an integrated approach, with host resistance as a major component, is generally considered best for controlling the disease (Hetzler et al., 1991; Mehta et al., 1992). The resistance to spot blotch in prominent cultivars has been slow due to quantitative nature of resistance which has a large influence of environment (Joshi et al., 2004a; Kumar et al., 2009). This is one of the reasons why selection of spot blotch resistant plants in breeding programmes becomes complicated. The agricultural research farm of Banaras Hindu University, Varanasi testing center used in this study fall under EGP having characteristics of warm-humid weather particularly at reproductive stage of the crop which provokes spot blotch disease.

Result of current study indicate significant differences among genotype, year and genotype $\times$ year for AUDPC percent, days to heading and plot yield exhibit considerable phenotypic variations. The negative correlation among earliness and spot blotch susceptibility was found (Dubin et al., 1998; Mahto, 2001; Rosyara et al., 2009) while AUDPC and days to heading was significantly and negatively correlated with plot yield. The similar results of Saxesena et al. (2017) also showed by developing recombinant inbred line population from cross of two parents YS\#58 $\times$ YS\#24 for spot blotch resistance. The value of plant genetic resources are realized only when each and every germplasm line is characterized for relevant traits to reveal new gene combinations for their use in crop improvement (Upadhyaya et al., 2010). Further, an association study on agro-morphological traits with spot blotch resistance will provide a roadmap in making selection strategy.
According to Heidari et al., 2016, GGE biplot facilitated visual comparison and informative methods to detect genotypes stability and in the preferential genotypes recommendations. This approach provides an easy and comprehensive analysis of genotype by years' interaction such that not only it allows effective evaluation of genotypes but also a comprehensive understanding of the target environment (year) (Yan \& Tinker, 2005). Genotypes showed variation for spot blotch score and morpho-agronomic traits. Current study identified superior lines for specific traits with resistance to spot blotch disease that are likely to serve as new potential sources of variation in wheat improvement programme. For AUDPC, the first two principal components explained $100 \%(\mathrm{PC} 1=75.13 \%$ and $\mathrm{PC} 2=24.87 \%)$ of the total variation of the year-centered data implying complex interaction between genotypes and year. The stability analysis of wheat genotypes is explained by performance line passing through the origin of the biplot showed that the germplasm 9122 , 9049 and 9239 was farthest to the left of the biplot origin and near to performance line indicating lower AUDPC mean. The more stable a genotype will be more near to the performance line as reported earlier by Yan et al., 2000 hence, these lines could be considered stable for spot blotch resistance across the years. Identification of genotypes with stable resistance for disease is an important component that ensures selection of appropriate sources of resistance for breeding programmes (Sharma et al., 2012; Singh et al., 2015). Using the ideal environment (year) as the centre, concentric circles were drawn to help visualize the distance between each environment and the ideal environment (Yan et al., 2000; Yan \& Rajcan, 2002).

The variation in plot yield was mainly affected by genotype and genotype $\times$ year interactions. The PC1 vs PC2 of genotypes and environments (years) explained $84.5 \%$ of the total variance. When a genotype is near to performance line and environment on the right side of origin of biplot, this indicates that the genotype is specifically adapted to that environment (Kumar et al., 2016). The highest mean value for plot yield was observed for the panel 9061, 9070, 9203 and 9216 which were found relatively more stable while 2014 was most discriminating year for plot yield. In breeding, an ideal genotype is regarded as the one that has the highest mean yield and is stable across environments (Yan \& Kang, 2003). Results of this study implied that genotypes possessing good spot blotch resistance, high yield potential and adaptation under spot blotch conducive environment could be used in wheat improvement programs for developing superior genotypes for yield and spot blotch resistance contributing to food security in south Asia.

\section{Acknowledgements}

Authors gratefully acknowledge Matthew P. Reynolds, CIMMYT, Mexico, for providing WAMI population. 


\section{Conflict of interest}

There is no conflict of interest to declare.

\section{References}

Aggarwal R, Singh VB, Shukla R, Gurjar MS, Gupta S, Sharma TR. (2010) URP-based DNA fingerprinting of Bipolaris sorokiniana isolates causing spot blotch of wheat. Journal of Phytopathology 158: 210-216.

Bai G, Shaner G (1994) Scab of Wheat: prospects for control. Plant Disease 78: 760-766.

Braun HJ, Atlin G, Payne T (2010) Multi-location testing as a tool to identify plant response to global climate change. In: Reynolds M.P, ed, Climate change and crop production. CABI, London, UK. pp. 115-138.

Chand R, Pandey SP, Singh HV, Kumar S, Joshi AK (2003) Variability and its probable cause in the natural populations of spot blotch pathogen Bipolaris sorokiniana of wheat (T. aestivum L.) in India. Journal of Plant Diseases and Protection 110: 27-35.

Chaurasia S, Joshi AK, Dhari R, Chand R (1999) Resistance to foliar blight of wheat; a search. Genetic Resources and Crop Evolution 46: 469-475.

Dubin HJ, Arun B, Begum SN, Bhatta M, Dhari R, Goel LB, Joshi AK, Khanna BM, Malaker PK, Pokhrel DR, Rahman MM, Saha NK, Shaheed MA, Sharma RC, Singh AK, Singh RM, Singh RV, Vergas M, Verma PC (1998) Results of the south Asia regional Helminthosporium leaf blight and yield experiment, 1993-94. In: Duveiller E, Dubin HJ, Reeves J, McNab A (Eds.), Helminthosporium Blights of Wheat: Spot Blotch and Tan Spot, CIMMYT, Mexico, D.F. Pp. 182-187.

Dubin HJ, Van Ginkel M (1991) The status of wheat diseases and disease research inwarmer areas. In: Saunders DA (Ed.), Wheat for the Nontraditional Warmer Areas. CIMMYT, Mexico, D.F, pp. 125-145.

Duveiller E (2003) Controlling foliar blight of wheat in rice-wheat system of Asia. Plant Disease 88: 52-56.

Duveiller E, Sharma RC (2009) Genetic improvement and crop management strategies to minimize yield losses in warm nontraditional wheat growing areas due to spot blotch pathogen Cochliobolus sativus. Journal of Plant Pathology157: 521-534.

FAOSTAT (2016) FAOSTAT. Food Agric. Organ. United Nations.

Fernandez MR, Fox SL, Hucl P, Singh AK (2014) Leaf spotting reaction of spring common durum and spelt wheat and Kamut under organic management in western. Canadian Journal of Plant Science 94: 929-935.
Giraldo P, Benavente E, Manzano-Agugliaro F, Gimenez E (2019) Worldwide Research Trends on Wheat and Barley: A Bibliometric Comparative Analysis. Agronomy 9: 352.

Heidari Shadi, Azizinezhad Reza, Haghparast Reza (2016) Yield stability analysis in advanced durum wheat genotypes by using AMMI and GGE biplot models under diverse environment. Indian Journal of Genetics $76: 274-283$.

Hetzler J, Eyal Z, Mehta YR, Campos LA (1991) Interaction between spot blotch (Cochliobolus sativus) and wheat cultivars. In: Saunders DA, Hettel G, eds. Wheat for Nontraditional Warm Areas. Mexico, DF: CIMMYT, 146-64.

Joshi AK, Chand R (2002) Variation and inheritance of leaf angle, and its association with spot blotch (Bipolaris sorokiniana) severity in wheat (Triticum aestivum). Euphytica 124: 283-291.

Joshi AK, Chand R, Kumar S, Singh RP (2004b) Leaf tip necrosis: a phenotypic marker associated with resistance to spot blotch disease in wheat. Crop Science 44:792-796.

Joshi AK, Ferrara O, Crossa G, Singh J, Alvarado J, Bhatta G, Duveiller MR, Sharma E, Pandit RC, Das SY, Chand R (2007a) Associations of environments in South Asia based on spot blotch disease of wheat caused by Cochliobolus sativus. Crop Science 47: 1071-1081.

Joshi AK, Kumar S, Chand R, Ortiz-Ferrara G (2004a) Inheritance of resistance to spot blotch caused by Bipolaris sorokiniana in spring wheat. Plant Breeding 123: 213-219.

Joshi AK, Mishra B, Chatrath R, Ortiz-Ferrara G, Singh RP (2007b) Wheat improvement in India: present status, emerging challenges and future prospects. Euphytica 157: 431-446.

Kumar U, Joshi AK, Kumar S, Chand R, Roder MS (2009) Mapping of resistance to spot blotch disease caused by Bipolaris sorokiniana in spring wheat. Theoretical and Applied Genetics 118: 783-792.

Kumar V, Kharub AS, Verma RPS, Verma A (2016) AMMI, GGE biplot and regression analysis to comprehend the $\mathrm{G} \times \mathrm{E}$ interaction in multi environment barley trials. Indian Journal of Genetics 76 : 202-204.

Mahto BN (2001) Effect of Helminthosporium leaf blight on yield components and determination of resistance in selected wheat varieties. Annals of Agricultural Sciences 22: 177-181.

Mehta YR, Riede CR, Campos LAC, Cooli MM (1992) Integrated management of major wheat diseases in Brazil: an example for southern cone region of Latin America. Crop Protection 11: 517-524. 
Panse VG, Sukhatme PV (1985) Statistical method for agricultural workers, $4^{\text {th }}$ edition, New Delhi.

Raemaekers RH (1988) Bipoloris sorokiniana disease complex on wheat and source of resistance in Zambia. In: Klatt AR (Eds.) wheat production constraints in tropical environment, Mexico. D.F. CIMMYT. 175-185.

Rosyara UR, Khadka K, Subedi S, Sharma RC, Duveiller E (2009) Field resistance to spot blotch is not associated with undesirable physio-morphological traits in three spring wheat populations. Journal of Plant Pathology 91 : 113-122.

Saari EE (1998) Leaf blight diseases and associated soil borne fungal pathogens of wheat in north and south East Asia. In: Duveiller E, Dubin HJ, Reeves J, Mc Nab A (Eds) Helminthosporium Blights of wheat: Spot Blotch and Tan Spot CIMMYT, Mexico, D.F. Pp. 37-51.

Saari EE, Prescott JM (1975) A scale for appraising the foliar intensity of wheat diseases. Plant Disease Report 59: 377- 380.

Saxesenaa RR, Mishra VK, Chand R, Chowdhury A, Kumar B, Prateek Madha, Joshi AK (2017) Pooling together spot blotch resistance, high yield with earliness in wheat for eastern Gangetic Plains of South Asia. Field Crops Research 214: 291-300.

Shaner G, Finney R (1977) The effect of nitrogen fertilization on the expression of slow mildewing in knox wheat. Phytopathology 67: 1051-1056.

Sharma M, Babu TK, Gaur PM, Ghosh R, Rameshwar T, Chaudhary RG, Upadhyay JP, Gupta O, Saxena DR, Kaur L, Dubey SC, Anandani VP, Harer PN, Pande S (2012) Identification and multienvironment validation of resistance to Fusarium oxysporum f. sp. ciceris in chickpea. Field Crops Research 135: 82-88.

Sharma RC, Duveiller E (2006) Spot blotch continues to cause substantial grain yield reductions under resource-limited farming conditions. Journal of Phytopathology 154: 482-488.

Shrestha KK, Timila RD, Mahto BN, Bimb HP (1998) Disease incidence and disease loss due to foliar blight of wheat in Nepal. In: Duveiller E, Dubin HJ, Reeves J, McNab A (Eds.), Helminthosporium Blights of Wheat: Spot Blotch and Tan Spot. CIMMYT, Mexico, D.F, pp. 67-72.

Singh PK, Zhang Y, Xinyao H, Singh RP, Chand R, Mishra VK, Malaker PK, Reza MA, Rahman MM, Islam R, Chowdhury AK, Bhattacharya PM, Kalappanavar I K, Crossa J, Joshi AK (2015) Development and characterization of the $4^{\text {th }}$ CSISA-spot blotch nursery of bread wheat. European Journal of Plant Pathology 143: 595-605.

Upadhyaya D, Sharma S, Ramulu B, Bhattacharjee R, Gowda CLL, Reddy VGG, Singh S (2010) Variation for qualitative and quantitative traits and identification of trait-specific sources in new sorghum germplasm. Crop and Pasture Science 61: 609-618

Yan W (2001) GGE biplot: a windows application for graphical analysis of multi-environment trial data and other types of twoway data. Agronomy Journal 93: 1111-1118.

Yan W, (2002) Singular-value partitioning in biplot analysis of multi environment trial data. Agronomy 94: 90-996.

Yan W, Fregeau-Reid J, Pageau D, Martin R, Mitchell-Fetch J, Etienne M, Sparry E (2010) Identifying essential test locations for oat breeding in Eastern Canada. Crop Science 50: 505-515.

Yan W, Hunt LA, Sheng QL, Szlavnics Z (2000) Cultivar evaluation and mega environment investigation based on the GGE biplot. Crop Science 40: 597-605.

Yan W, Kang MS (2003) GGE biplot analysis: A graphical tool for breeders, geneticists, and agronomists (pp. 63-88). Boca Raton, FL: CRC Press.

Yan W, Rajcan I (2002) Biplot analysis of test sites and trait relations of soybean in Ontario. Crop Science 42: 11-20.

Yan W, Tinker NA (2005) An integrated biplot analysis system for displaying, interpreting, and exploring genotype-by environment interactions. Crop Science 45: 1004-1016. 